\title{
Les comptes des consuls de Montferrand (1346-1373), édités par R. Anthony Lodge
}

\section{Walter Meliga}

\section{(2) OpenEdition}

1 Journals

\section{Edizione digitale}

URL: http://journals.openedition.org/studifrancesi/3646

DOI: 10.4000/studifrancesi.3646

ISSN: 2421-5856

\section{Editore}

Rosenberg \& Sellier

\section{Edizione cartacea}

Data di pubblicazione: 1 décembre 2012

Paginazione: 543

ISSN: 0039-2944

\section{Notizia bibliografica digitale}

Walter Meliga, «Les comptes des consuls de Montferrand (1346-1373), édités par R. Anthony Lodge»,

Studi Francesi [Online], 168 (LVI | III) | 2012, online dal 30 novembre 2015, consultato il 05 mars 2021. URL: http://journals.openedition.org/studifrancesi/3646; DOI: https://doi.org/10.4000/studifrancesi. 3646

Questo documento è stato generato automaticamente il 5 mars 2021.

\section{(c) $(1) \ominus$}

Studi Francesi è distribuita con Licenza Creative Commons Attribuzione - Non commerciale - Non opere derivate 4.0 Internazionale. 


\section{Les comptes des consuls de Montferrand (1346-1373), édités par R. Anthony Lodge}

Walter Meliga

\section{NOTIZIA}

Les comptes des consuls de Montferrand (1346-1373), édités par R. Anthony LODGE, Paris, École de Chartes, 2010 («Études et rencontres de l'École de Chartes», 31), pp. 621.

1 Terzo volume dell'edizione dei conti degli archivi medievali di Montferrand, dopo il primo del 1985 (Le plus ancien registre de comptes des consuls de Montferrand en provençal auvergnat. 1259-1272, Clermont-Ferrand, 1985), e il secondo del 2006 (Les comptes des consuls de Montferrand (1273-1319), édités par R. Anthony Lodge, Paris, École de Chartes, 2006: si veda «Studi Francesi», LIII, 158, p. 370). Come nel volume precedente, anche in questo l'edizione dei documenti è preceduta da un'introduzione che tocca in particolare la loro lingua, osservata nella sua evoluzione fino al limite del xIV secolo. 